University of Arkansas, Fayetteville

ScholarWorks@UARK

Graduate Theses and Dissertations

8-2019

\title{
Estimating Demand Elasticities for Rice in Benin
}

Ogoudele Simon Codjo

University of Arkansas, Fayetteville

Follow this and additional works at: https://scholarworks.uark.edu/etd

Part of the Agribusiness Commons, Agricultural Economics Commons, and the Food Security Commons

\section{Citation}

Codjo, O. S. (2019). Estimating Demand Elasticities for Rice in Benin. Graduate Theses and Dissertations Retrieved from https://scholarworks.uark.edu/etd/3394

This Thesis is brought to you for free and open access by ScholarWorks@UARK. It has been accepted for inclusion in Graduate Theses and Dissertations by an authorized administrator of ScholarWorks@UARK. For more information, please contact scholar@uark.edu. 
Estimating Demand Elasticities for Rice in Benin

A thesis submitted in partial fulfillment of the requirements for the degree of

Master of Science in Agricultural Economics

by

Ogoudele Simon Codjo

University of Parakou

Agricultural Economics Engineer Diploma, 2011

August 2019

University of Arkansas

This thesis is approved for recommendation to the Graduate Council.

Alvaro Durand Morat, Ph.D.

Thesis Director

Lawton Lanier Nalley, Ph.D.

Committee Member

Rodolfo N. Nayga, Jr., Ph.D.

Committee Member

Eric J. Wailes, Ph.D.

Committee Member 


\begin{abstract}
Rice consumption in Benin is increasing along with shifting consumer demand toward higher quality rice. In this context of changing demands, experimental estimation methods provide an effective way to estimate the current state of consumer preferences. We conducted a hypothetical choice experiment in 15 open markets in Benin to analyze the demand for rice and its substitutes. The results reveal that consumers value quality rice, even those in the low-income class. While high income consumers are more likely to choose high quality imported rice, lowand middle-income consumers are more likely to select high quality domestic rice among the set of rice available. In the high-income group, the demand for high quality imported and domestic rice is price inelastic. High quality domestic rice is almost as likely as high quality imported rice to be selected by urban consumers. In the rural area, consumers are highly responsive to rice price change. Whereas, the demand for rice in the urban area is price inelastic. Consumers are not responsive to corn price changes across the three income groups, although corn is the most likely commodity to be chosen by low- and middle-income consumers. The results suggest that any increase in rice prices could have an untoward effect on rice consumption in urban area.
\end{abstract}




\section{ACKNOWLEDGEMENTS}

I owe the success of this thesis to the contribution of many people and the support of the Fulbright program. I would like to say a special thanks to the William J. Fulbright scholarship program for this exceptional opportunity to study in the United States. I might never have obtained the opportunity to study in the United States and have the chance to expand my cultural background without Fulbright scholarship.

I owe a special thanks to my supervisor, Dr. Alvaro Durand-Morat, for his support during my Master's degree program. He ceaselessly invested efforts to comment on the drafts of my proposal and thesis. His pertinent and rigorous comments helped me improve my research work and my knowledge. By looking at the first draft and the final version of my thesis, I realized a huge gap and I owe this achievement to the guidance of Dr. Durand-Morat. I am also grateful to Dr. Lanier Nalley who was of a special support throughout my proposal development and my data analysis. His insightful advice was helpful to overcome many hurdles to this thesis.

I would like to thank the faculty members who taught me various classes or provided me with support to improve my knowledge during my stay at University of Arkansas. I would like to acknowledge Dr. Bruce Dixon, Dr. Eric Wailes, and Dr. Rodolfo Nayga. My thankfulness also goes to Dr. Daniel Rainey and Ms. Alicia Minden for their support about the different administrative processes during my program. Also, I cannot forget the assistance that I received from Mr. Grant West and Mr. Wei Yang. Both of them devoted time to assist me in my research design and for the data analysis.

Finally, I am thankful for the support of my siblings, Victor, Elvire, Emma, Evariste, Eustache, Martine, Sabine, and Mathieu Codjo. 


\section{DEDICATION}

To my father, Ogoudaré Samuel Codjo;

to my mother, Salomé Bola Etienne;

to my Spouse, Irene Ayaba Noudehou, and

to my son, Ayomidé Nael Albert Codjo. 


\section{TABLE OF CONTENTS}

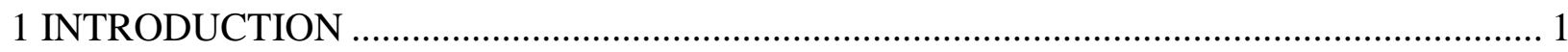

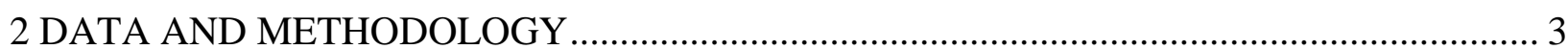

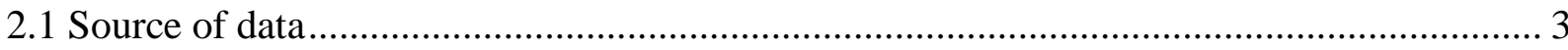

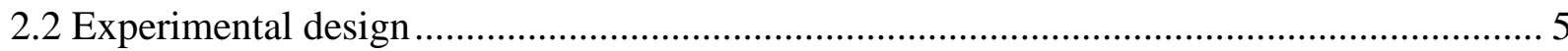

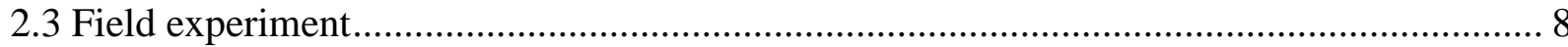

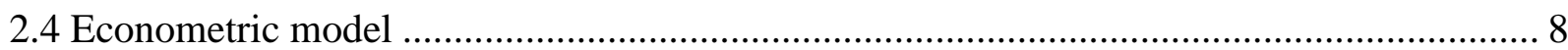

2.5 Estimation of price elasticity of demand for rice .......................................................... 10

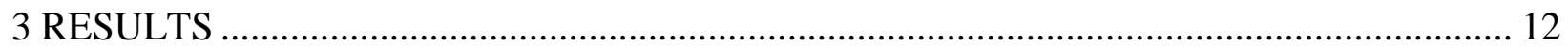

3.1 Characteristics of respondents by income group and by location ..................................... 12

3.2 Results of the random parameter logit model by income group and by location................. 15

3.3 Estimation of market shares by income group and by location ....................................... 19

3.4 Estimation of direct and cross elasticities by income group and by location ..................... 20

3.5 Implied demand curves for rice by income group and by location ................................... 24

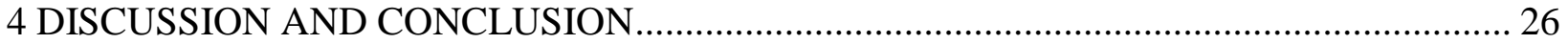

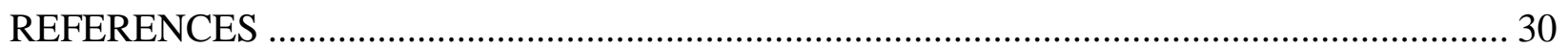

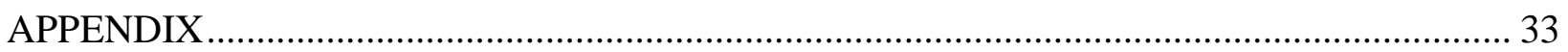




\section{LIST OF FIGURES}

Figure 1: Geographical distribution of rice production in 2017 and selected urban and rural

markets included in the survey based on Benin direction of agricultural statistics data.

Figure 2: Implied Demand Curves for Rice by Income Group and by Location ...................... 25 


\section{LIST OF TABLES}

Table 1. Distribution of the Respondents Across the Fifteen Markets Surveyed in Benin ........... 5

Table 2. Physical Quality Indicators of the Rice Used in the Choice Experiment ....................... 6

Table 3. Prices Used for the Choice Experiment Design (FCFA/kg) .................................... 7

Table 4. Socioeconomics Characteristics of Respondents by Income Group and by Location ... 14

Table 5. Estimates of Random Parameter Model per Income Group and by Location ............... 17

Table 6. Estimated Market Shares (\%) per Income Group and by Location ............................. 20

Table 7. Arc Price Elasticities by Income Group and by Location ......................................... 22

Table 8: Percentage Change in the Demand of the Selected Staples Due to a $10 \%$ Increase in the

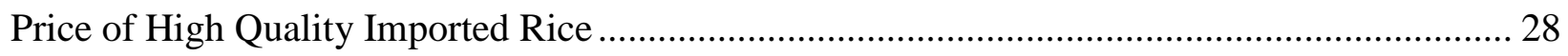

Table 9 : Percentage Change in the Demand of the Selected Staples Due to a 10\% Decrease in

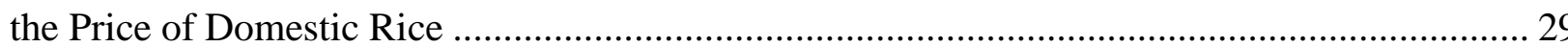




\section{INTRODUCTION}

In Benin, rice consumption is growing faster than that of any other food commodity. Between 1992 and 2002, per capita rice consumption increased by 25.25\% and between 2003 and 2013, it surged to $150.42 \%$ (FAOSTAT, 2018). This rapid growth in total rice consumption is linked to urbanization, increasing incomes, and shifting urban consumer preferences that favor rice consumption (Fofana, Goundan, \& Domgho, 2014; Demont \& Neven, 2013). According to FAOSTAT (2018), rice is the main source of calories for consumers in Benin and contributed in 2013 approximately $21 \%$ of the daily caloric intake, followed by yam, corn, and cassava, which provide around $16 \%, 13 \%$, and $12 \%$ of the daily caloric intake, respectively. Accordingly, rice plays a vital role in maintaining food security in Benin, and any shock that negatively affects rice price and availability might result in social instability (Seck et al, 2013), and worsen food insecurity. In Benin, 9.6\% of households are food insecure and $42 \%$ are at the edge of food security, meaning that they can become food insecure when severe shocks occur (WFP, 2017).

Despite the formidable growth in rice production in the last decade since the rice market crisis of 2007/08, domestic production supplies only a quarter of the national rice demand since 2014 (USDA, 2018). One of the major reasons for the dependence on imports is the low investments in the domestic rice sector needed to increase production. West African countries endowed with ports, including Benin, find it more affordable to import rice instead of investing in the domestic rice sector (Rutsaert, Demont, \&Verbeke, 2013; Aker et al, 2010; Bezemer \& Headey, 2008). Such reliance on imports may jeopardize long run food security, making the domestic market vulnerable to global rice price volatility (Laroche, Dupraz \& Postolle, 2013). A blatant example is the 2007 food crisis that exacerbated food insecurity in both rural and urban areas of developing countries (Demont \& Neven, 2013). However, policies protecting domestic 
production can negatively affect households' welfare, primarily low-income households that use a large share of income on food, especially if prices rise as a result of the policies (GyimahBrempong \& Kuku-Shittu, 2016). Price-related shocks could adversely affect Benin's rural and urban consumers since they spend about $51 \%$ and $47 \%$ of their income on food, respectively (WFP, 2014). Hence, policy makers need to have appropriate information to design sound and balanced rice policies to expand domestic production without compromising consumers' welfare.

The design of suitable rice policies that ensures households' food security and enhance their welfare requires a clear understanding of rice consumption patterns and the welfare implications of sectoral policies. According to Lusk and Tonsor (2016), new dimensions of demand might arise over time along with new information and economic conditions. The fastgrowing rice consumption in Benin requires the understanding of the new dynamic of rice demand that can help in the formulation of more effective interventions. Moreover, the impact of changes in households' purchasing power requires an understanding of the differences in consumer preferences by income groups. (Leathers \& Foster, 2004; Pinstrup-Andersen and Caicedo, 1978, Cuevas et al, 2016; Lusk and Tonsor, 2016). Elasticity estimates for population's income profiles could aid policymakers in the formulation of better policies that account for the possible differences/sensibilities across income groups. Despite the rapidly changing and growing rice market, there are no recent studies on rice demand estimation in Benin.

One of the challenges of estimating a food demand system in Benin is the quality and availability of data. Systematic historical information on food prices and consumption in Benin are not available, but this shortcoming can be addressed using a consumer survey approach such as choice experiment (Lusk and Tonsor, 2016). In addition, aggregate disappearance data might not be perfectly correlated with actual consumption and may not exhibit much information on 
preferences heterogeneity (Piggott and Marsh 2004; Tonsor, Mintert, and Schroeder 2010). According to Unnevehr et al (2010), new methods such as experimental survey have cropped up in recent years to improve the prediction of consumers' preferences and choices. As a result, changes in consumers' preferences can be identified and the effect of policies on consumers' welfare predicted. The fast-growing Benin rice consumption and the rapidly changing consumers preference suggest that the use of demand estimation method, like experimental modelling, can be the most appropriate approach to assess consumer preferences. This study uses data from a hypothetical choice experiment to: (i) estimate the own and cross price elasticities of demand for staple foods in Benin; (ii) evaluate consumers substitution pattern between the different staples; and (iii) determine the variation of substitution pattern across income groups in Benin and between rural and urban area.

\section{DATA AND METHODOLOGY}

\subsection{Source of data}

A consumer survey was conducted in January 2019 in fifteen open markets, including seven urban markets, across the southern, central, and northern regions of Benin (Figure 1). In southern Benin, the surveys were mainly conducted in Cotonou, the main rice consumption area. In the central Benin, the Collines department, the second largest rice production area in the country, was selected. The northern areas selected for this study encompasses some minor rice production zones, such as Barienou and Kolokondé. A total of three hundred and three (303) consumers were interviewed. Table 1 presents the distribution of the respondents in the sample. 


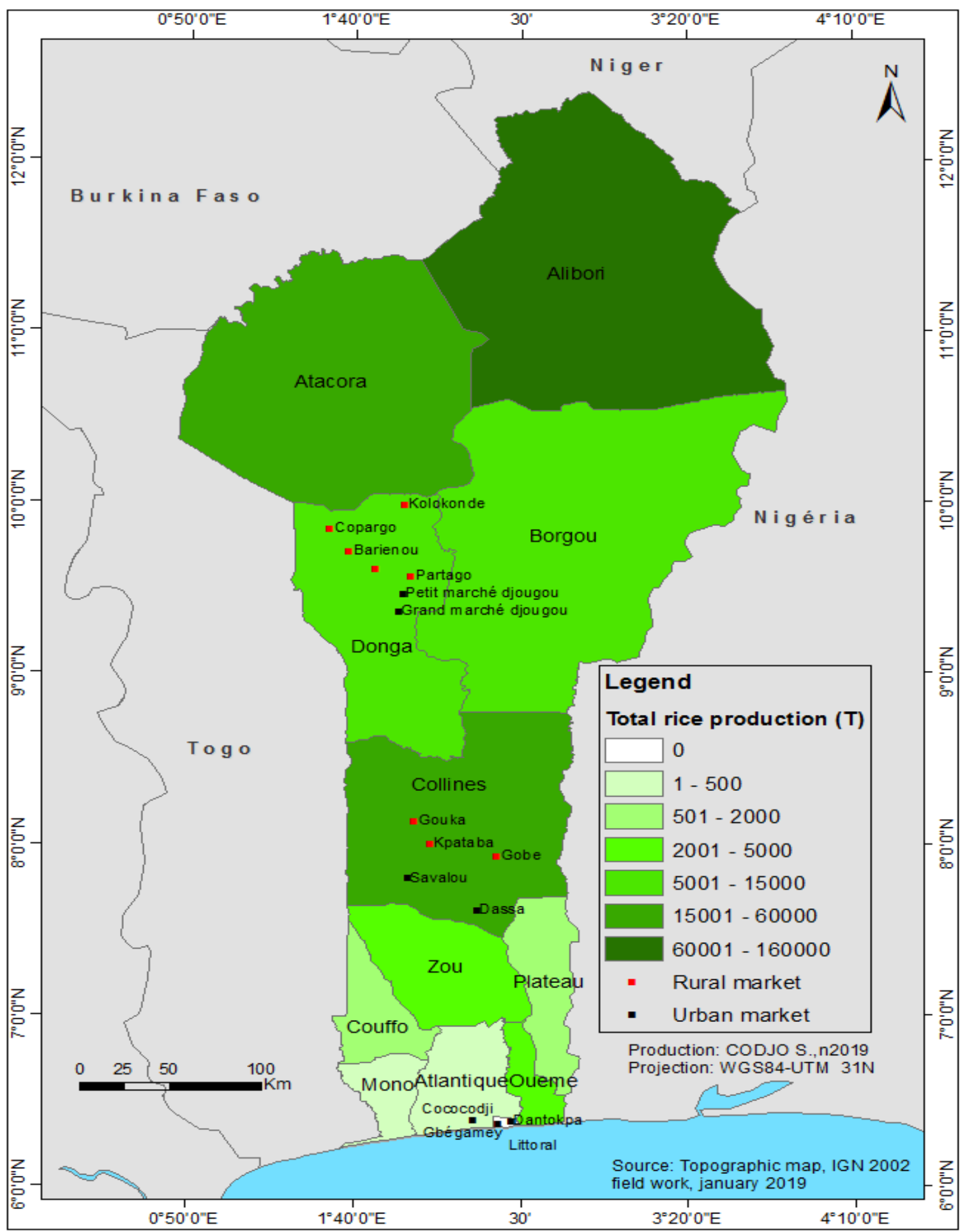

Figure 1: Geographical distribution of rice production in 2017 and selected urban and rural markets included in the survey based on Benin direction of agricultural statistics data. 
Table 1. Distribution of the Respondents Across the Fifteen Markets Surveyed in Benin

\begin{tabular}{|c|c|c|c|c|c|}
\hline Region & Total & Location & Market names & $\begin{array}{l}\text { Number of } \\
\text { respondents }\end{array}$ & Total \\
\hline \multirow{3}{*}{ Southern } & \multirow{3}{*}{107} & \multirow{3}{*}{ Urban } & Dantokpa & 40 & \multirow{3}{*}{107} \\
\hline & & & Gbegamey & 37 & \\
\hline & & & Cococodji & 30 & \\
\hline \multirow{6}{*}{ Central } & \multirow{6}{*}{104} & \multirow{3}{*}{ Urban } & Savalou & 24 & \multirow{3}{*}{50} \\
\hline & & & & & \\
\hline & & & Dassa & 26 & \\
\hline & & \multirow{3}{*}{ Rural } & Gobé & 25 & \multirow{3}{*}{54} \\
\hline & & & Kpataba & 11 & \\
\hline & & & Gouka & 18 & \\
\hline \multirow{8}{*}{ Northern } & \multirow{8}{*}{92} & \multirow{3}{*}{ Urban } & Grand marché Djougou & 21 & \multirow{3}{*}{27} \\
\hline & & & & & \\
\hline & & & Petit marché Djougou & 06 & \\
\hline & & \multirow{5}{*}{ Rural } & Paparapanga & 16 & \multirow{5}{*}{65} \\
\hline & & & Kolokonde & 13 & \\
\hline & & & Barienou & 12 & \\
\hline & & & Copargo & 14 & \\
\hline & & & Partago & 10 & \\
\hline Total & 303 & & & 303 & 303 \\
\hline
\end{tabular}

\subsection{Experimental design}

This study uses a hypothetical choice experiment to gather data on consumer preferences for the selected staple foods, including rice and its substitutes. Respondents were presented with nine choice sets and were asked to select one option from each choice set. Each choice set has seven 
alternatives: high quality imported rice, high quality domestic rice, standard quality domestic rice, yam, corn, cassava, and a "no purchase" alternative. Following Demont, Fiamohe, and Kinkpe (2017), we considered the variety Nerica 2, IR841, and Gino rice as the standard quality rice, highquality domestic rice, and high-quality imported rice, respectively. The variety IR841 is processed using modern milling technology. However, the variety Nerica is processed using the traditional milling equipment. Gino is the most popular imported rice brand in urban areas and is notorious for its high quality (Demont, Fiamohe, and Kinkpe, 2017). The samples of the rice used in this study underwent physical analysis in the rice lab of Food Science Department of University of Arkansas. The lab analysis of the physical attributes of Nerica 2, IR841, and Gino rice are presented in table 2. Based on International Rice Research Institute (IRRI) grain classification system, the rice considered are all long grain rice However, the high-quality imported rice is classified as slender and both qualities domestic rice are of intermediate shape. In addition, imported rice displays less chalk and broken rate than the high and standard quality domestic rice.

Table 2. Physical Quality Indicators of the Rice Used in the Choice Experiment

\begin{tabular}{cccccc}
\hline Rice & $\begin{array}{c}\text { Length }^{1} \\
(\mathbf{m m})\end{array}$ & $\begin{array}{c}\text { Width } \\
(\mathbf{m m})\end{array}$ & $\begin{array}{c}\text { Shape }^{2} \\
(\text { Length/width })\end{array}$ & $\begin{array}{c}\text { Chalk } \\
\text { impact }\end{array}$ & $\begin{array}{c}\text { Broken } \\
\text { rate (\%) }\end{array}$ \\
\hline High quality imported (Gino) & 6.72 & 2.14 & 3.14 & 0.6 & 1.6 \\
High quality domestic (IR841) & 6.79 & 2.38 & 2.85 & 5.12 & 7.4 \\
Standard domestic (NERICA2) & 6.04 & 2.39 & 2.53 & 19.63 & 17.7 \\
\hline
\end{tabular}

\footnotetext{
${ }^{1}$ Rice grain length classification based on IRRI classification system: short $(<5.50 \mathrm{~mm})$, medium/intermediate $(5.51-6.60 \mathrm{~mm})$, long $(6.61-7.50 \mathrm{~mm})$, and very long $(>7.50 \mathrm{~mm})$.

${ }^{2}$ Rice grain shape classification based on IRRI classification system: bold $(<2.0)$, medium (2.1-3.0), and slender (> 3.0)
}

Each choice set displays the same alternatives, but different prices levels. The substitutes and the no-buy alternative are purposely included in the choice experiment to allow rice 
consumers to shift out of rice into other food alternatives or a no buy alternative as part of their choice, thus reflecting real market experiences more accurately (Lusk and Tonsor, 2016). Three levels of prices were considered for each product (low, mid, and high price). The mid-price is the average market price of the product published by the National Institute of Statistic and Economic Analysis from November 12 to November 18 (INSAE, 2018). For some products, such as standard quality rice, which are not included in the market aforementioned report, we estimated the market price from a survey of 3 open markets conducted in Cotonou in, in Glazoué, and Djougou in November of 2018. The December market prices of the products were not used because of the possible distortion in price due to the Christmas and new year celebration. To obtain the low and high price of each product, 200 CFA francs (FCFA) were subtracted from and added to the mid-price. Table 3 presents the details of the price levels of the products used for the choice experiment.

Table 3. Prices Used for the Choice Experiment Design (FCFA/kg)

\begin{tabular}{lccc}
\hline Products & Low & Mid & High \\
\hline High quality imported rice & 900 & 1100 & 1300 \\
High quality domestic rice & 300 & 500 & 700 \\
Standard quality domestic rice & 150 & 350 & 550 \\
Corn & 50 & 200 & 400 \\
Cassava & 75 & 250 & 450 \\
Yam & 100 & 300 & 500 \\
\hline Avera
\end{tabular}

Average exchange rate December $2018=576$ FCFA/US $\$$

An orthogonal factorial experimental design was used to develop 27 choice tasks. Three blocks of nine choices were constructed using the 27 choice tasks, and each respondent was randomly 
assigned to one block. Throughout the survey, the order of the alternatives was randomly varied across respondents.

\subsection{Field experiment}

To ensure that the survey accurately reflected market experiences, we conducted face-toface surveys in market stands selling staples in the selected open markets. We compensated stand owners for shelf space to display the six staple foods considered in this study. We standardized the presentation of the products (e.g., the containers used to hold the staples were of the same color and size) to make the experiment condition homogenous. We randomly selected consumers that came to the market to buy staples, but before they completed the purchase. The invitation consisted of explaining the objective of the study to the respondent and the benefit of participating in the experiment. Participants received 1,500 FCFA (US\$3) as compensation for their time. Each participant was randomly assigned a choice task block and responded nine choice sets question. Respondents were allowed to visually inspect the six staple foods, but were not told about the quality indicators of the different kind of rice considered in this study. Respondents completed a socioeconomic questionnaire before conducting the choice experiment.

\subsection{Econometric model}

Random utility maximization (RUM) model is used as guidelines for the choice data analysis (McFadden 1973). The RUM model presumes that agent utility is composed of a deterministic component and a stochastic unobserved error component. Given this framework, the utility $\mathrm{U}_{\mathrm{ij}}$ that a decision maker $\mathrm{i}$ derives from consuming alternative $\mathrm{j}$ may be portioned into a deterministic and observed component, $\mathrm{V}_{\mathrm{ij}}$, and a stochastic and unobserved component, $\varepsilon_{\mathrm{ij}}$, such that: 


$$
U_{i j}=V_{i j}+\varepsilon_{i j}
$$

The choice of the model of estimation of $U_{i j}$ depends on assumptions about the distribution of the unmodeled component, $\varepsilon_{i j}$. Assuming that the $\varepsilon_{i j}$ follow a type 1 extreme value distribution and are independently and identically distributed (IID) across $i$ and $j$, then the conventional multinomial logit model (MNL) can be used to model the choice probability associated with alternative $\mathrm{j}$. Equation 2 presents the choice probability of alternative $\mathrm{j}$ :

$$
\operatorname{Prob}(i \text { choose } j)=\frac{e^{V_{i j}}}{\sum_{k=1}^{7} e^{V_{i k}}}
$$

The observed component, $V_{i j}$, is assumed to be linear in parameters such that:

$$
V_{i j}=\beta_{j} x_{i j}
$$

Where $x_{i j}$ is a vector of observed variables describing alternative $\mathrm{j}$, and $\beta_{j}$ are the coefficients associated with these variables. The MNL exhibits two main limitations in its use for elasticities computation (Luck and Tensor, 2016). First, all cross-price elasticities for an alternative are identical because of the independence of the irrelevant alternative (IIA) property of the MNL. Second, the deterministic component of the utility function, $\mathrm{V}_{\mathrm{ij}}$, assumes that the marginal utility of a price change is constant and identical for all alternatives. A less restrictive utility function can be obtained by modifying the functional form of $\mathrm{V}_{\mathrm{ij}}$ as follows:

$$
V_{i j}=\beta_{j}+\alpha P_{j}
$$

Where $P_{j}$ is the price of alternative $\mathrm{j}, \alpha$ is the marginal utility of price change, and $\beta_{j}$ is the alternative specific constant associated with alternative $\mathrm{j}$. Although equation 4 is less restrictive, the IIA assumption of the MNL still prevails. One option to relax the IIA assumption is to use a random parameter logit (RPL) which assumes that preferences may vary across 
respondents (Henser, Rose, and Greene, 2015). Moreover, the RPL model can approximate any RUM model (McFadden and Train, 2000). It allows for the variation of random taste, substitution patterns without restriction, and unobserved factors correlation (Train, 2009). In this study, we adopted the following functional form of the observed utility function:

$$
V_{i j}=\beta_{j}+\sum_{t=1}^{6} \omega_{j t} d_{i t}+\alpha_{j} P_{j}
$$

Where, as before, $\beta_{j}$ represents the alternative specific constant associated with alternative $\mathrm{j}, P_{j}$ is the price of alternative $\mathrm{j}$, and $\alpha_{j}$ the marginal utility of price change associated with alternative $\mathrm{j}$. The terms $d_{i t} \sim N(0,1)$ and $\omega_{j t}$ are the elements of the lower triangular Cholesky matrix associated with the covariance matrix of the random parameters.

\subsection{Estimation of price elasticity of demand for rice}

This study focusses on both the own and the cross-price demand elasticities. In this econometric framework, the own-price demand elasticity is assessed as the percentage change in the likelihood of selecting alternative $j$ in the choice set with respect to the percentage change in the price of $j$. Similarly, cross-price elasticities are estimated as the percentage change in the likelihood of selecting alternative $j$ in the choice set with respect to the percentage change in the price of alternative $k$ (Louvier et al, 2000). To estimate these elasticities, we first estimated the market share as the probability of purchase for individual $i$ and food option $j$ at different price levels. Second, the demand curve is constructed using the market share as a function of price. Finally, the elasticity or percentage change in the market share of good $j$ that results from a $1 \%$ increase in the price of good $k$ is calculated. 


\section{i) Estimation of market share}

The market shares are estimated by plugging the observable component of utility, $\widehat{V_{l J}}$, in the probability equation (2):

$$
S_{i j} \mid d_{i}=\frac{e^{\widehat{V_{l j}}}}{\sum_{k=1}^{7} e^{\widehat{V_{l k}}}}
$$

Where $S_{\mathrm{ij}}$ is the market share or probability of purchase for individual $\mathrm{i}$ and food option $\mathrm{j}$, and $d_{i}$ is a vector containing the terms $d_{i t}$. Equation 6 cannot be directly evaluated because it contains the random terms $d_{i t} \sim N(0,1)$, and simulation must be used to approximate the mean share. For a set of $N$ draws from $d_{i t} \sim N(0,1)$, the unconditional market share for food option $\mathrm{j}$, $S_{j}$, can be approximated as follows:

$$
S_{j}=\frac{1}{N} \sum_{t=1}^{N} \frac{e^{\widehat{V_{l j}}}}{\sum_{k=1}^{7} e^{\widehat{V_{l k}}}}
$$

\section{ii) Construction of demand curve}

The demand curve for good $j$ is constructed by evaluating equation (7) at different good

$j$ 's prices holding the price of other goods at their mean value. For instance, we build the demand curve for standard quality rice by evaluating its market share at 150, 250, 350, 450, and 550 FCFA $\mathrm{kg}^{-1}$, keeping the price of high quality imported rice, high quality domestic rice, yam, cassava, and corn at 1100, 500, 350, 300, 250, 200 FCFA. The prices considered for each staple food should vary within the price range used in the experimental design. The implied demand curve for each staple food is constructed by plotting the prices and associated market shares. 


\section{iii) Estimation of elasticities or change in market share}

The final value of the elasticity, defined as the percentage change in the share of good $j$ that results from a $1 \%$ increase in the price of good $k$ is calculated as:

$$
e_{j k}=\frac{S_{j}^{\prime}-\bar{S}_{j}}{\bar{s}_{j}} \frac{1}{0.1}
$$

Where $e_{j k}$ the arc elasticity of demand for good $j$, or percentage change in the share of

good $j$ that results from a $1 \%$ increase in the price of $\operatorname{good} k, \bar{S}_{j}$ is the market share of good $j$ evaluated at the midpoint price level, and $S_{j}^{\prime}$ is the new market share of good $j$ resulting from a $10 \%$ increase in the price of good $k$.

\section{RESULTS}

\subsection{Characteristics of respondents by income group and by location}

Table 4 presents the socio-economic characteristics of the respondents by income group. We grouped respondents into low, middle, and high-income groups following the distribution presented in the report of the Benin global analysis of vulnerability and food security (WFP, 2014). The categorization per income group in this study suggests that $45 \%, 39 \%$, and $16 \%$ of the respondents are in the low, middle, and high-income groups, respectively. Thus, our sample resembles the national distribution reported by AGSVA (2014), by which 40\%, 40\%, and $20 \%$ of households are in the low, middle, and high-income categories. A Kruskal-Wallis test revealed that there is a significant $(\mathrm{P}<0.01)$ difference in the rice purchase price, per capita rice consumption, and household size across income groups. The average purchase price of rice increases from the low to the high-income class: high-income consumers pay $41.2 \%$ and $35.7 \%$ more than low and middle-income households. The average annual per capita consumption of rice is estimated at $29 \mathrm{~kg}$, which is less than the $42 \mathrm{Kg}$ per capita per year estimated by Fiamohe 
and Kinkpe (2016). High income respondents consume more rice than low- and middle-income consumers. The average household size is 4.98, 6.00, and 6.02 for low, middle, and high-income consumers, respectively. The average respondents' household size is 5.55 , which is close to the national average of 5.85 (RGPH, 2013). Twenty eight percent of the respondents did not have any formal education. The high-income class presents the highest proportions of university level respondents, while the low-income respondents had the highest proportion of illiterate.

A Wilcoxon test revealed that there is a significant $(\mathrm{P}<0.01)$ difference between the rice purchase price, per capita rice consumption, and the size of rural and urban households. Rice is much cheaper in rural areas, which may be explained by the fact that cheaper domestic rice may be more popular in rural areas than in urban areas. Rural households display a larger size, which reflects the national profile of households distribution. The national average households' size is estimated at 5.01 and 6.08 for urban and rural areas, respectively. Likewise, urban area households consume more rice than rural area households. This may be explained by urbanization that stimulates the consumption of foods, such as rice, that are easier to cook and need less preparation time. With urbanization, the opportunity cost of women's time increases since they have a greater chance to work outside home. Furthermore, many people have their lunch outside home and rice is a convenient food. Lastly, urban households are more literate than their rural counterpart. 
Table 4. Socioeconomics Characteristics of Respondents by Income Group and by Location

\begin{tabular}{|c|c|c|c|c|c|c|}
\hline & \multirow[b]{2}{*}{ Pooled } & \multicolumn{3}{|c|}{ Income Group } & \multicolumn{2}{|c|}{ Location } \\
\hline & & $\begin{array}{c}\text { Low } \\
\text { Income }^{1}\end{array}$ & $\begin{array}{c}\text { Middle } \\
\text { Income }^{2}\end{array}$ & $\begin{array}{c}\text { High } \\
\text { Income }^{3}\end{array}$ & $\begin{array}{l}\text { Rural } \\
\text { Area }\end{array}$ & $\begin{array}{c}\text { Urban } \\
\text { Area }\end{array}$ \\
\hline Rice price (FCFA/kg) & $\begin{array}{c}525 \\
(236.07)\end{array}$ & $\begin{array}{c}484.9 \\
(214.9)\end{array}$ & $\begin{array}{c}504.9 \\
(205.5)\end{array}$ & $\begin{array}{c}684.9 \\
(289.6)\end{array}$ & $\begin{array}{c}433.78 \\
(154.35)\end{array}$ & $\begin{array}{r}584.13 \\
(260)\end{array}$ \\
\hline Rice consumption & 28.95 & 29.09 & 27.87 & 31.21 & 25.38 & 31.27 \\
\hline (kg/capita) & $(17.55)$ & (19.73) & $(14.25)$ & $(18.23)$ & $(14.03)$ & (19.14) \\
\hline Household size & $\begin{array}{l}5.55 \\
(2.49)\end{array}$ & $\begin{array}{l}4.98 \\
(2.14)\end{array}$ & $\begin{array}{c}6.00 \\
(2.51)\end{array}$ & $\begin{array}{c}6.02 \\
(2.94)\end{array}$ & $\begin{array}{c}6.1 \\
(2.7)\end{array}$ & $\begin{array}{c}5.19 \\
(2.27)\end{array}$ \\
\hline Formal education (\%) & & & & & & \\
\hline Yes & 72.27 & 62.23 & 73.95 & 95.92 & 62.19 & 78.80 \\
\hline No & 27.72 & 37.77 & 26.05 & 4.08 & 37.81 & 21.19 \\
\hline Marital status (\%) & & & & & & \\
\hline Yes & 74.25 & 67.41 & 81.51 & 75.51 & 77.31 & 72.28 \\
\hline No & 25.75 & 32.59 & 18.49 & 24.49 & 22.69 & 27.77 \\
\hline $\begin{array}{l}\text { Number of } \\
\text { respondents }\end{array}$ & 303 & 135 & 119 & 49 & 119 & 184 \\
\hline
\end{tabular}

Standard deviation in parenthesis; MI=Monthly income in FCFA; Average exchange rate December $2018=576$ FCFA/US $\$$

1 . Monthly income $\leq 100,000{ }^{2} .100,000<$ monthly income $\leq 200,000{ }^{3}$. Monthly income $>$ 200,000 . 


\subsection{Results of the random parameter logit model by income group and by location}

Since the RPL model yielded a better fit than the MNL model for all the specifications used in this study, and given the advantages of RPL over MNL discussed above, we focus the discussion on the RPL model estimates. The Bayesian information criterion (BIC), Akaike information criterion (AIC), and likelihood ratio (LR) test suggest that the RPL model with a correlated alternative specific constant yields better results than the uncorrelated RPL model.

The sum of the log likelihood values of the three income group models is compared to the pooled model $\log$ likelihood function value to see if the model parameters are the same across income groups (Lusk and Tonsor, 2016). The comparison yields a chi-squared value of 224.36 with 78 degrees of freedom and an associated p-value less than .001. Accordingly, preferences are different across income groups since the hypothesis that the model parameters are identical across income categories is rejected.

Table 5 presents the results of the correlated RPL model for the pooled data set and for the three income groups. The results indicate that all the parameters depict the expected signs and are statistically significant $(\mathrm{P}<0.01)$. In the pooled model, the high-quality domestic rice presents a coefficient of 8.089 , which is the highest among the three types of rice. This coefficient indicates that the average consumer receives 8.089 more utility from high quality domestic rice than from the no buying option. High quality domestic rice provides 4.484 (8.0893.605) more utility than high quality imported rice. We identify important differences in the utility derived from the different types of rice by household income levels. High-quality domestic rice shows the highest utility among the three types of rice for both low- and middleincome households, while high-quality imported rice provides the highest utility to the average high-income consumer. Low-income consumers derive no utility (coefficient statistically not 
different from zero) from high-quality imported rice. For staples other than rice, the average consumer across all income levels derives the highest utility from corn and lowest from cassava.

The price coefficients in Table 4 report the marginal utility of price change. For example, the coefficient of -0.008 for high quality domestic rice in the pooled model indicates that an increase of FCFA 100 in the price of high-quality domestic rice will decrease utility by 0.8. For all staples (including the three types of rice) and income groups, the marginal utility is negative and significantly different from zero. We use the variance and the covariance of the alternative specific constant to assess heterogeneity across consumers. For example, the standard deviation for high quality domestic rice in the pooled sample is 2.5 and significantly different from zero, which means that we should expect that $68 \%$ of the consumers in that income group derive a utility from high quality domestic rice of between 5.59 and $10.59(8.089 \pm 2.5)$. Appendix Table 2 shows the correlation matrix for random parameters implied by the variancecovariance matrix.

Similarly to the case of income categories, we test the null hypothesis that the models are the same across locations (rural and urban). The likelihood test yields a chi-squared of 217.52 with 78 degrees of freedom and an associated p-value less than .001, which leads to the rejection of the null hypothesis. The results of the correlated RPL model for rural and urban area show that all the parameters have the expected signs and are statistically significant, except for the marginal utility of price for cassava, which is not statistically different from zero. High quality domestic rice gives the highest utility to rural and urban households among the rice alternatives. Concerning the food commodities other than rice, corn provides the highest utility for consumers in both locations. The significance of the variance of the alternative specific constants for all rice alternatives highlights the heterogeneity in preferences among rural and urban households. 
Table 5. Estimates of Random Parameter Model per Income Group and by Location

\begin{tabular}{|c|c|c|c|c|c|c|}
\hline & \multirow[b]{2}{*}{ Pooled } & \multicolumn{3}{|c|}{ Income Group } & \multicolumn{2}{|c|}{ Location } \\
\hline & & $\begin{array}{c}\text { Low } \\
\text { Income }^{1}\end{array}$ & $\begin{array}{c}\text { Middle } \\
\text { Income }^{2}\end{array}$ & $\begin{array}{c}\text { High } \\
\text { Income }^{3}\end{array}$ & $\begin{array}{l}\text { Rural } \\
\text { Area }\end{array}$ & $\begin{array}{l}\text { Urban } \\
\text { Area }\end{array}$ \\
\hline \multicolumn{7}{|c|}{ Alternative Specific Constants } \\
\hline $\mathrm{HQIR}^{4}$ & $\begin{array}{l}3.605 * * \\
(1.293)\end{array}$ & $\begin{array}{l}-6.238 \\
(3.799)\end{array}$ & $\begin{array}{c}7.309 * * * \\
(1.902)\end{array}$ & $\begin{array}{c}7.117 * * * \\
(2.001)\end{array}$ & $\begin{array}{c}0.84 \\
(3.63)\end{array}$ & $\begin{array}{c}10.09 * * * \\
(1.47)\end{array}$ \\
\hline $\mathrm{HQDR}^{5}$ & $\begin{array}{c}8.089 * * * \\
(0.58)\end{array}$ & $\begin{array}{c}6.383 * * * \\
(0.669)\end{array}$ & $\begin{array}{c}9.466 * * * \\
(0.865)\end{array}$ & $\begin{array}{c}3.103^{* * *} \\
(1.1)\end{array}$ & $\begin{array}{c}9.2 * * * \\
(0.82)\end{array}$ & $\begin{array}{c}10.59 * * * \\
(1.78)\end{array}$ \\
\hline $\mathrm{SQDR}^{6}$ & $\begin{array}{c}7.73 * * * \\
(0.562)\end{array}$ & $\begin{array}{c}6.075 * * * \\
(0.661)\end{array}$ & $\begin{array}{c}7.674 * * * \\
(0.752)\end{array}$ & $\begin{array}{l}4.9 * * * \\
(0.919)\end{array}$ & $\begin{array}{c}8.47 * * * \\
(0.68)\end{array}$ & $\begin{array}{c}9.71 * * * \\
(1.67)\end{array}$ \\
\hline Yam & $\begin{array}{c}8.468 * * * \\
(0.582)\end{array}$ & $\begin{array}{l}6.22 * * * \\
(0.604)\end{array}$ & $\begin{array}{c}8.438 * * * \\
(0.732)\end{array}$ & $\begin{array}{c}5.856^{* * *} \\
(0.829)\end{array}$ & $\begin{array}{c}9.27 * * * \\
(0.7)\end{array}$ & $\begin{array}{c}10.56 * * * \\
(1.45)\end{array}$ \\
\hline Cassava & $\begin{array}{c}7.391 * * * \\
(0.585)\end{array}$ & $\begin{array}{c}5.983 * * * \\
(0.654)\end{array}$ & $\begin{array}{c}6.168 * * * \\
(0.762)\end{array}$ & $\begin{array}{c}5.186^{* * *} \\
(1.42)\end{array}$ & $\begin{array}{c}11.37 \\
(22.79)\end{array}$ & $\begin{array}{c}9.49 * * * \\
(1.58)\end{array}$ \\
\hline Corn & $\begin{array}{c}8.816^{* * * *} \\
(0.582)\end{array}$ & $\begin{array}{c}6.639 * * * \\
(0.609)\end{array}$ & $\begin{array}{c}8.805 * * * \\
(0.738)\end{array}$ & $\begin{array}{c}6.302 * * * \\
(0.856)\end{array}$ & $\begin{array}{c}9.35 * * * \\
(0.7)\end{array}$ & $\begin{array}{c}10.88 * * * \\
(1.54)\end{array}$ \\
\hline Price Ef & & & & & & \\
\hline HQIR & $\begin{array}{c}-0.006^{* * *} \\
(0.001)\end{array}$ & $\begin{array}{c}-0.007 * * * \\
(0.002)\end{array}$ & $\begin{array}{c}-0.008 * * * \\
(0.002)\end{array}$ & $\begin{array}{c}-0.005^{* *} \\
(0.002)\end{array}$ & $\begin{array}{c}-0.007 * * \\
(0)\end{array}$ & $\begin{array}{c}-0.006 * * * \\
(0)\end{array}$ \\
\hline HQDR & $\begin{array}{c}-0.008 * * * \\
(0.001)\end{array}$ & $\begin{array}{c}-0.007 * * * \\
(0.001)\end{array}$ & $\begin{array}{c}-0.013 * * * \\
(0.001)\end{array}$ & $\begin{array}{c}-0.006 * * * \\
(0.002)\end{array}$ & $\begin{array}{c}-0.014 * * * \\
(0)\end{array}$ & $\begin{array}{c}-0.006 * * * \\
(0)\end{array}$ \\
\hline LQDR & $\begin{array}{c}-0.011 * * * \\
(0.001)\end{array}$ & $\begin{array}{c}-0.01 * * * \\
(0.001)\end{array}$ & $\begin{array}{c}-0.015 * * * \\
(0.001)\end{array}$ & $\begin{array}{c}-0.014 * * * \\
(0.002)\end{array}$ & $\begin{array}{c}-0.018 * * * \\
(0)\end{array}$ & $\begin{array}{c}-0.009 * * * \\
(0)\end{array}$ \\
\hline Yam & $\begin{array}{c}-0.013 * * * \\
(0.001)\end{array}$ & $\begin{array}{c}-0.014 * * * \\
(0.001)\end{array}$ & $\begin{array}{c}-0.016 * * * \\
(0.001)\end{array}$ & $\begin{array}{c}-0.011^{* * *} \\
(0.001)\end{array}$ & $\begin{array}{c}-0.021 * * * \\
(0)\end{array}$ & $\begin{array}{c}-0.011 * * * \\
(0)\end{array}$ \\
\hline
\end{tabular}


Table 5. (Continued).

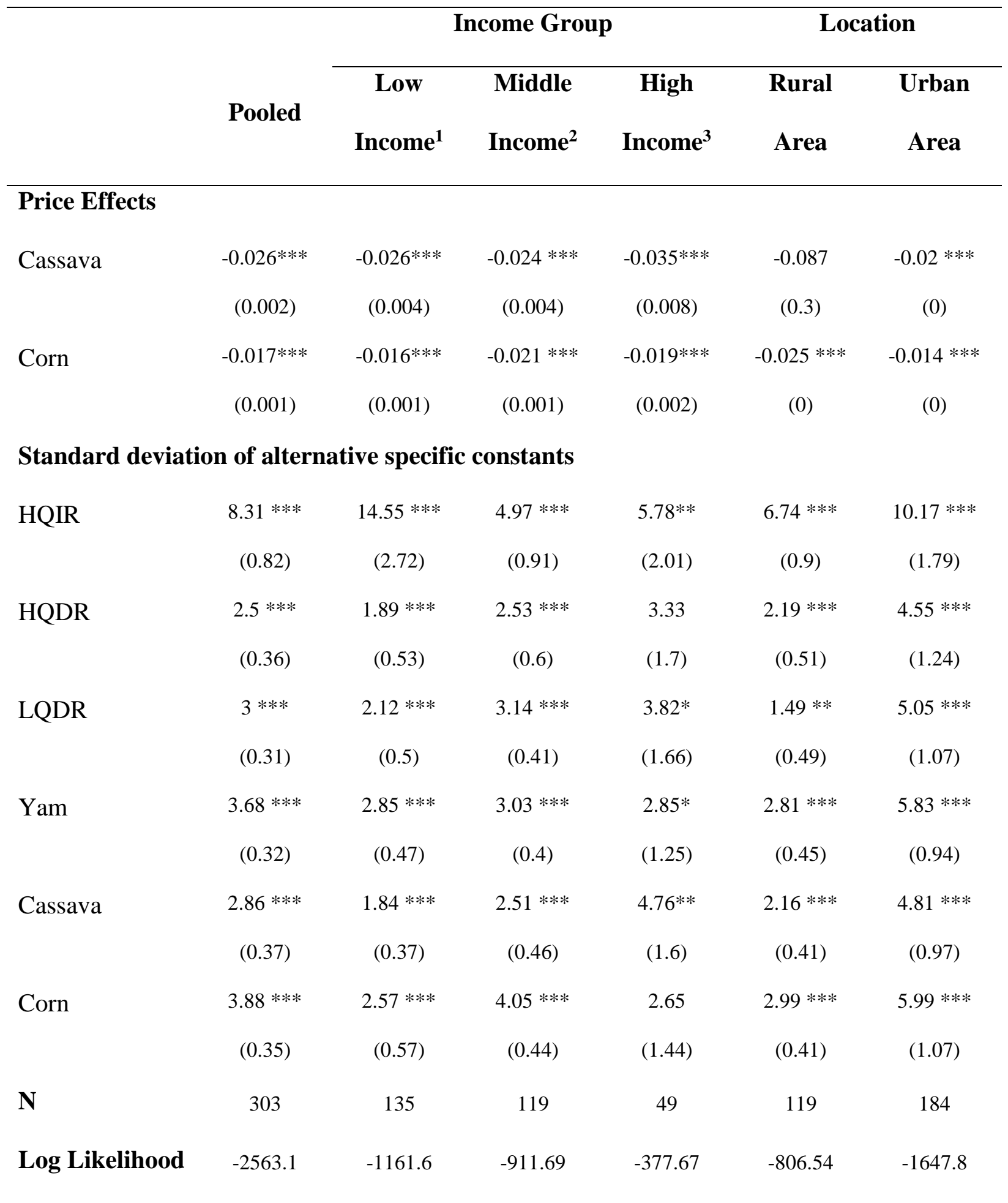

Standard errors in parenthesis; ' $* * *,,{ }^{* *}$ ', ' $*$ ', significance at 1,5 , and $10 \%$.

${ }^{1}$. Monthly income $\leq 100,000{ }^{2} .100,000<$ monthly income $\leq 200,000{ }^{3}$. Monthly income $>$ 200,000 .

${ }^{4}$. High quality imported rice. ${ }^{5}$. High quality domestic rice. ${ }^{6}$. Standard quality domestic rice. 


\subsection{Estimation of market shares by income group and by location}

The comparison of parameters across income classes may be inappropriate since it may be confounded by the discrepancy between variances (Lusk and Tonsor, 2016). However, the market shares, which indicate the probability of purchasing a product, can be compared across income groups. Table 6 presents the distribution of market shares across income groups and location. High income class consumers are almost 3 and 5 times more likely to choose high quality imported rice than low- and middle-income classes consumers. High quality domestic rice is more likely to be selected by both low- and middle-income households than high quality imported rice and standard quality domestic rice. Corn has the largest market share among the low- and middle-income classes, and high-quality imported rice has the largest share among high-income households. Among all the products, cassava is less likely to be chosen across all income groups.

Urban households are 50\% more likely to choose rice than rural household. Actually, rice accounts for $51 \%$ of the market share of urban consumers versus $34 \%$ for rural consumers. The market share of high-quality imported rice among rural households is very small, while it is the largest for urban households. Urban households have a similar market share for the three rice alternatives. Corn has the largest market share among all the food products in both rural and urban area. The probability of no purchase is small across income groups and urban and rural households. 
Table 6. Estimated Market Shares (\%) per Income Group and by Location

\begin{tabular}{|c|c|c|c|c|c|c|}
\hline \multirow[b]{2}{*}{ Products } & \multirow[b]{2}{*}{ Pooled } & \multicolumn{3}{|c|}{ Income group } & \multicolumn{2}{|c|}{ Location } \\
\hline & & $\begin{array}{c}\text { Low } \\
\text { Income } \\
1\end{array}$ & $\begin{array}{l}\text { Middle } \\
\text { Income } \\
2\end{array}$ & $\begin{array}{c}\text { High } \\
\text { Income }^{3}\end{array}$ & Rural & Urban \\
\hline $\mathrm{HQIR}^{4}$ & 11.39 & 9.32 & 6.05 & 30.05 & 4.32 & 18.46 \\
\hline $\mathrm{HQDR}^{5}$ & 18.41 & 23.00 & 16.52 & 10.33 & 16.45 & 17.35 \\
\hline SQDR $^{6}$ & 17.86 & 21.63 & 16.19 & 11.56 & 13.68 & 15.76 \\
\hline Yam & 23.75 & 19.27 & 27.38 & 27.33 & 30.39 & 21.12 \\
\hline Cassava & 1.84 & 1.04 & 2.29 & 2.97 & 0.01 & 5.73 \\
\hline Corn & 25.80 & 24.76 & 31.02 & 15.99 & 34.04 & 21.58 \\
\hline No purchase & 0.93 & 0.97 & 0.55 & 1.77 & 1.13 & 0.01 \\
\hline
\end{tabular}

${ }^{1}$. Monthly income $\leq 100,000 .^{2} .100,000<$ monthly income $\leq 200,000{ }^{3}$. Monthly income $>$ 200,000.

${ }^{4}$. High quality imported rice. ${ }^{5}$. High quality domestic rice. ${ }^{6}$. Standard quality domestic rice.

\subsection{Estimation of direct and cross elasticities by income group and by location}

Table 7 presents the own and cross-price elasticities of demand by income group and by location. Overall, the demand for all rice alternatives is elastic across income groups, except for high quality imported and domestic rice for high-income consumers. A $10 \%$ decrease in the price of standard quality domestic rice will result in a $4.1 \%$ decrease in the high-quality domestic rice consumption among low-income consumers. Similarly, the demand for high quality domestic rice by middle income consumers is expected to decrease by $4.4 \%$ as a result of $10 \%$ decrease in high quality imported rice price. Hence, high-quality domestic rice is the most preferred rice by low- and middle-income consumers. Looking at high-income consumers, a $10 \%$ increase in the price of high-quality imported rice will result in $9.6 \%, 0.4 \%$, and $0.5 \%$ decrease in the 
consumption of high-quality imported rice, high quality domestic rice, and standard quality domestic rice respectively. Rural consumers are highly responsive to food price changes. A $10 \%$ decrease in the price of standard quality domestic rice will result in the $9.6 \%$ reduction in the consumption of high-quality domestic rice in the rural areas. However, a $10 \%$ fall in the price of standard quality domestic rice will lead to only $1.3 \%$ decrease in the consumption of high-quality domestic rice consumption in urban area. Among urban households, the demand for all rice alternatives is inelastic. Accordingly, rice is more a staple food in urban area than in rural area.

Looking at the products other than rice, corn demand is inelastic across income groups and locations. Interestingly, corn is a closer substitute for domestic high-quality rice among low and middle-income households: the cross-price elasticity of corn for high quality domestic rice, the most preferred rice alternative among low and middle-income households, is the largest among all staples. A $10 \%$ increase in price of rice regardless the quality, will result in a $3 \%$ to $3.8 \%$ increase in corn consumption for low income consumers, $4.6 \%$ to $10.6 \%$ among middle income consumers, and $1.4 \%$ to $4.1 \%$ among high-income consumers. The demand for yam is elastic for low- and middle-income consumers but inelastic for high-income respondents. However, the demand for cassava is elastic across the income groups. Standard quality domestic rice presents the largest cross price elasticity of cassava demand among low- and middle-income consumers. Thus, these consumers will substitute more standard quality domestic rice to cassava than the other commodities. 
Table 7. Arc Price Elasticities by Income Group and by Location

\begin{tabular}{|c|c|c|c|c|c|c|}
\hline \multirow[b]{2}{*}{$\%$ Change in price } & \multicolumn{6}{|c|}{$\%$ Change in quantity } \\
\hline & HQIR & HQDR & $\begin{array}{l}\text { SQDR } \\
\end{array}$ & Yam & Cassava & Corn \\
\hline \multicolumn{7}{|l|}{ Low Income $^{1}$} \\
\hline $\mathrm{HQIR}^{4}$ & -1.08 & -0.03 & -0.03 & -0.43 & -0.08 & 0.3 \\
\hline $\mathrm{HQDR}^{5}$ & 0.1 & -1.48 & 0.38 & 0.24 & 0.15 & 0.38 \\
\hline SQDR $^{6}$ & 0.06 & 0.41 & -1.89 & 0.39 & 0.12 & 0.34 \\
\hline Yam & 0.07 & 0.49 & 0.55 & -2.48 & -0.09 & 0.44 \\
\hline Cassava & 0.13 & 0.52 & 0.68 & 0.84 & -4.67 & 0.39 \\
\hline Corn & 0.16 & 0.6 & 0.46 & 0.48 & 0.01 & -0.82 \\
\hline No purchase & 0.41 & 0.61 & 0.47 & 0.7 & -0.06 & 0.54 \\
\hline \multicolumn{7}{|l|}{ Middle Income $^{2}$} \\
\hline HQIR & -2.69 & 0.44 & -0.07 & 0.26 & -0.38 & 1.06 \\
\hline HQDR & 0.16 & -2.28 & 0.47 & 0.64 & 0.2 & 0.74 \\
\hline SQDR & 0.08 & 0.51 & -1.79 & 0.24 & 0.18 & 0.46 \\
\hline Yam & 0.24 & 0.25 & 0.45 & -1.46 & 0.25 & 0.3 \\
\hline Cassava & 0.29 & 0.41 & 0.96 & 0.32 & -3.1 & 0.18 \\
\hline Corn & 0.12 & 0.39 & 0.13 & 0.5 & -0.01 & -0.8 \\
\hline No purchase & 0.24 & 1.27 & 0.88 & 1.2 & 0.35 & 0.51 \\
\hline \multicolumn{7}{|l|}{ High Income I $^{3}$} \\
\hline HQIR & -0.91 & -0.04 & -0.05 & 0.19 & 0.07 & 0.19 \\
\hline HQDR & 0.63 & -0.94 & 0.04 & 0.53 & 0.23 & 0.23 \\
\hline SQDR & 0.17 & 0.15 & -1.67 & 0.42 & 0.29 & 0.58 \\
\hline Yam & 0.48 & 0.3 & 0.33 & -0.95 & 0.25 & 0.27 \\
\hline Cassava & -0.04 & 0.07 & -0.23 & 0.43 & -3.15 & 0.16 \\
\hline
\end{tabular}


Table 7. (Continued).

Change in quantity

\begin{tabular}{|c|c|c|c|c|c|c|}
\hline \multirow{2}{*}{ Change in price } & \\
\hline & $\begin{array}{l}\text { HQIR } \\
\end{array}$ & HQDR & $\begin{array}{l}\text { SQDR } \\
\end{array}$ & Yam & Cassava & Corn \\
\hline \multicolumn{7}{|l|}{ High Income ${ }^{3}$} \\
\hline Corn & 0.27 & 0.01 & 0.48 & 0.28 & -0.07 & -1.02 \\
\hline No purchase & 0.32 & 0.37 & 0.32 & 0.85 & 0.55 & 0.86 \\
\hline \multicolumn{7}{|l|}{ Rural area } \\
\hline HQIR & -2.09 & -0.08 & 0.45 & 0.79 & 0.21 & 0 \\
\hline HQDR & -0.04 & -2.96 & 0.69 & 0.99 & -0.15 & 0.81 \\
\hline SQDR & -0.02 & 0.93 & -2.97 & 0.97 & 0.19 & 1.01 \\
\hline Yam & 0.27 & 0.42 & 0.34 & -1.8 & -0.02 & 0.85 \\
\hline Cassava & -2.18 & -0.8 & 4.92 & -1.72 & -9.55 & 1.18 \\
\hline Corn & 0.04 & 0.37 & 0.21 & 0.39 & -0.01 & -0.94 \\
\hline No purchase & -0.04 & 1.18 & 1.64 & 1.43 & 0.16 & 0.99 \\
\hline \multicolumn{7}{|l|}{ Urban area } \\
\hline HQIR & -0.96 & 0.2 & -0.09 & 0.05 & 0.17 & 0.14 \\
\hline HQDR & 0.06 & -0.66 & 0.17 & 0.37 & 0.24 & 0.41 \\
\hline SQDR & 0.46 & 0.13 & -0.85 & 0.41 & 0.04 & 0.16 \\
\hline Yam & 0.15 & 0.17 & 0.3 & -0.83 & -0.02 & 0.1 \\
\hline Cassava & 0.58 & 0.25 & 0.18 & 0.2 & -1.44 & 0.1 \\
\hline Corn & 0.1 & 0.02 & 0.18 & 0.1 & 0.09 & -0.59 \\
\hline No purchase & 3.46 & 2.03 & 2.06 & 5.32 & 2.21 & 1.24 \\
\hline
\end{tabular}

${ }^{1}$. Monthly income $\leq 100,000 .{ }^{2} .100,000<$ monthly income $\leq 200,000 .{ }^{3}$. Monthly income $>200,000$.

${ }^{4}$. High quality imported rice. ${ }^{5}$. High quality domestic rice. ${ }^{6}$. Standard quality domestic rice. 


\subsection{Implied demand curves for rice by income group and by location}

The rice demand curves by income class and location are constructed using the market shares in the range of the prices used for the experimental design (Figure 2). All the demand curves depict a downward slope as expected according to the law of demand. The demand curves of the high-quality imported rice (HQIR) reveal that there is a gap between the demand of this rice at the lowest price (900 FCFA) across income groups and between rural and urban area. The likelihood of purchasing HQIR at the 900 FCFA is exceedingly higher for high income and urban area consumers. At the highest price of HQIR, the probability of choosing this rice is still substantially higher for high income and urban consumers than the probability of selecting this rice by rural and low-income consumers at the lowest price. Accordingly, HQIR may be more consumed in the urban areas and by high-income consumers even at the higher prices.

The demand for high quality domestic rice (HQDR) at its lowest price is higher for lowand middle-income consumers than that of high-income consumers. Similarly, the likelihood of choosing this rice in rural area is higher than in urban area at its lowest price. However, as the HQDR price increases, rural, low, and middle-income consumers' demand fall quickly, which is not the case for high-income consumers. Accordingly, the demand for HQDR is elastic in rural area and for low- and middle-income consumers as suggested by the elasticities estimates (Table 8). At the highest price of HQDR, the likelihood of choosing this rice by low-income consumers is higher than that of middle- and high-income consumers. This shows that consumers, even those of low-income profile, are aware of rice quality.

The demand for standard quality domestic rice (SQDR), is elastic across income groups and for rural consumers. In opposite, urban consumers have an inelastic demand for SQDR as shown by the shape of its demand curve. At the highest price of SQDR, low-income consumers 
depict the biggest demand for standard quality rice. Accordingly, low-income households may consume more standard domestic quality rice.
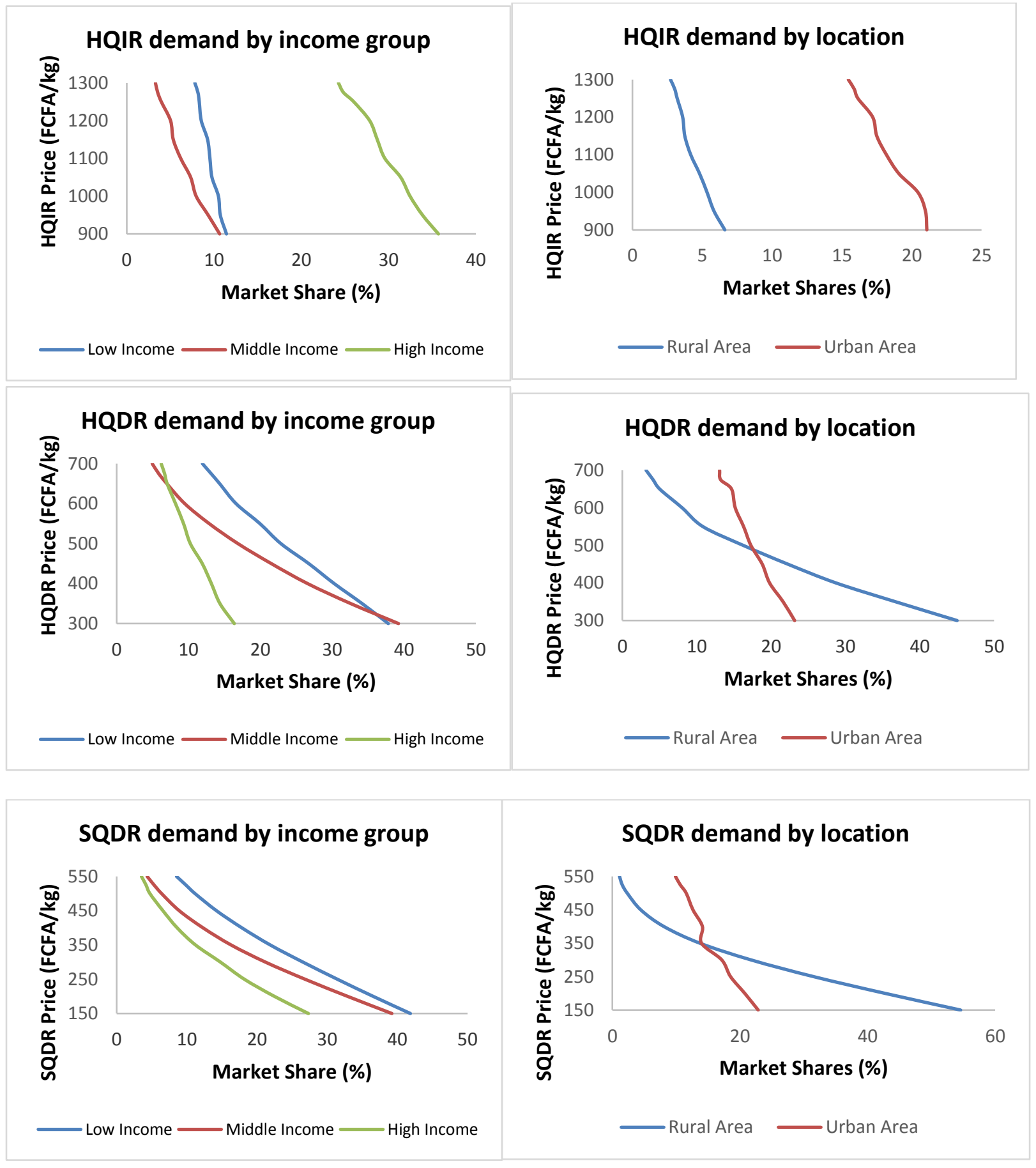

Figure 2: Implied Demand Curves for Rice by Income Group and by Location 


\section{DISCUSSION AND CONCLUSION}

Rice represents a significant food commodity in households' consumption in Benin and the understanding of its demand pattern is pivotal to design appropriate food policies. One of the main limitations in Benin is the lack of information to conduct a rigorous food demand analysis. To our knowledge, Benin has not conducted a household income and expenditure survey in the last decade, a time when food consumption, especially rice, changed significantly. We collected primary information via a consumer survey and used experimental methods to model the demand for rice in Benin. The results revealed several interesting and novel demand patterns. First, regardless of income level, consumers value/prefer high quality rice. This result is congruent with previous studies that suggest that rice consumers, even those of low-income class, are increasingly becoming aware of food quality (Rutsaert, Demont, \& Verbeke, 2013; Demont, Fiamohe, \& Kinkpe, 2017). Second, consumers in general are more sensitive to changes in rice prices than what the scarce existing literature suggests. To illustrate, Seale, Regmi, and Berstein (2003) estimated an unconditional own price elasticity of demand for bread and cereals, including rice, at -0.459 , which is significantly lower than the estimates generated in this study. Third, the own price demand elasticity varies significantly by income group and location. Highincome consumers exhibit an inelastic own price demand for high quality imported rice, their preferred option among all staples with a market share of 30 percent, while middle and lowincome consumers show an elastic response to the price of high quality domestic rice, their preferred rice option. Likewise, urban consumers have inelastic demands for all three rice options, while rural consumers are highly sensitive to changes in the price of high quality domestic rice, their preferred rice option. Lastly, substitution between imported and domestic rice is limited as evidenced by the small cross-price elasticity values, but varies by income level. 
Low-income consumers are less willing to substitute imported for domestic rice than middle and high-income consumers.

Since the rice crisis of 2007/08, Benin along with many other African countries have embarked in a plan to improve its rice supply chain and rice self-sufficiency. Benin developed its National Rice Development Strategy (NRDS) in 2011with the overarching goal of becoming rice self-sufficiency by 2018, but despite progress since then domestic production covers only around a quarter of domestic consumption. The findings of this study can help with the formulation of sound sectoral policies aimed at fostering the growth of the domestic rice sector by providing basic information to facilitate the impact analysis of relative changes in the price of imported and domestic rice.

Our findings suggest that a rice development strategy based on import market protection will not generate a large push in the demand for domestic rice, and will actually hurt consumers, primarily those from the high-income and urban groups. Table 8 shows the change in the demand for staple foods resulting from a 10 percent increase in the price of high quality imported rice. Demand for imported rice is estimated to decrease significantly by 17 percent nationwide while the demand for high quality domestic rice, its closest substitute, increases by 2 percent. The results show that such a policy intervention will have a clear bias against high-income groups that consume more imported rice, while it will have much smaller impacts on middle and lowincome groups. 
Table 8: Percentage Change in the Demand of the Selected Staples Due to a $10 \%$ Increase in the Price of High Quality Imported Rice

\begin{tabular}{|c|c|c|c|c|c|c|}
\hline & $\mathrm{HQIR}^{4}$ & $\mathrm{HQDR}^{5}$ & $\mathrm{SQDR}^{6}$ & Yam & Cassava & Corn \\
\hline Low Income $^{1}$ & $-11 \%$ & $0 \%$ & $0 \%$ & $-4 \%$ & $-1 \%$ & $3 \%$ \\
\hline Middle Income 2 & $-27 \%$ & $4 \%$ & $-1 \%$ & $3 \%$ & $-4 \%$ & $11 \%$ \\
\hline High Income $^{3}$ & $-9 \%$ & $0 \%$ & $-1 \%$ & $2 \%$ & $1 \%$ & $2 \%$ \\
\hline All income groups ${ }^{\dagger}$ & $-17 \%$ & $2 \%$ & $-1 \%$ & $0 \%$ & $-2 \%$ & $6 \%$ \\
\hline
\end{tabular}

${ }^{1}$. Monthly income $\leq 100,000 .{ }^{2} .100,000<$ monthly income $\leq 200,000{ }^{3}$. Monthly income $>$ 200,000 .

${ }^{4}$. High quality imported rice. ${ }^{5}$. High quality domestic rice. ${ }^{6}$. Standard quality domestic rice. $\dagger$. The aggregation across income groups is based on the population shares by income group from AGSVA (2014)

On the other hand, policies aimed at lowering the production cost and retail price of domestic rice can generate a sizable increase in the demand for domestic rice. As Table 9 shows, the demand for domestic high and standard quality rice increases by 13 percent and 15 percent, respectively, due to a $10 \%$ decrease in the price of domestic rice, while the demand for imported rice decreases by 3 percent. Also, we can expect that the benefits from lower domestic rice prices be more evenly distributed across income groups. 
Table 9 : Percentage Change in the Demand of the Selected Staples Due to a 10\% Decrease in the Price of Domestic Rice

\begin{tabular}{lrrrrrr}
\hline & HQIR $^{4}$ & HQDR $^{5}$ & SQDR $^{6}$ & Yam & Cassava & \multicolumn{2}{l}{ Corn } \\
\hline Low Income $^{1}$ & $-2 \%$ & $11 \%$ & $15 \%$ & $-6 \%$ & $-3 \%$ & $-7 \%$ \\
Middle Income $^{2}$ & $-2 \%$ & $18 \%$ & $13 \%$ & $-9 \%$ & $-4 \%$ & $-12 \%$ \\
High Income $^{3}$ & $-8 \%$ & $8 \%$ & $16 \%$ & $-10 \%$ & $-5 \%$ & $-8 \%$ \\
All income groups $^{\dagger}$ & $-3 \%$ & $13 \%$ & $15 \%$ & $-8 \%$ & $-4 \%$ & $-9 \%$ \\
\hline
\end{tabular}

${ }^{1}$. Monthly income $\leq 100,000 .{ }^{2} \cdot 100,000<$ monthly income $\leq 200,000 .{ }^{3}$. Monthly income $>$ 200,000 .

${ }^{4}$. High quality imported rice. ${ }^{5}$. High quality domestic rice. ${ }^{6}$. Standard quality domestic rice. $\dagger$. The aggregation across income groups is based on the population shares by income group from AGSVA (2014)

Finally, our findings highlight the importance of improving the quality of domestic rice to bring it up to par with imported rice. Based on the representative rice qualities used in this study, our findings suggest that changes in relative prices can improve demand for domestic rice only so much, and that quality upgrades to domestic rice are a must if Benin intends to significantly improve its rice self-sufficiency. 


\section{REFERENCES}

Arinloye, D. D. A. A (2006). Analysis of factors determining rice demand in center and south of Benin. Thesis of Agricultural Engineer, University of Abomey-Calavi, Benin.

Aker, J. C., Block, S., Ramachandran, V., \& Timmer, C. P. (2010). West African experience with the world rice crisis, 2007-2008. The rice crisis: markets, policies and food security, 143-162.

Bezemer, D., \& Headey, D. (2008). Agriculture, development, and urban bias. World Development, 36(8), 1342-1364.

Cuevas, R. P., Pede, V. O., McKinley, J., Velarde, O., \& Demont, M. (2016). Rice grain quality and consumer preferences: a case study of two rural towns in the Philippines. PloS one, 11(3), $\mathrm{e} 0150345$.

Demont, M., Fiamohe, R., \& Kinkpe, A. T. (2017). Comparative advantage in demand and the development of rice value chains in West Africa. World Development, 96, 578-590.

Demont, M., \& Neven, D. (2013). Tailoring African Rice Value Chains to Consumers. Realizing Africa's Rice Promise, 303.

Diagana, B., Akindes, F., Savadogo, K., Reardon, T. and Staatz, J. (1999) Effects of the CFA franc devaluation on urban food consumption in West Africa: overview and cross-country comparisons. Food Policy 24, 465-478.

Dupraz, C. L., \& Postolle, A. (2013). Food sovereignty and agricultural trade policy commitments: How much leeway do West African nations have? Food Policy, 38, 115-125.

FAOSTAT (2018). Data base accessed on March, 152018.

Fiamohe, R. E., \& Kinkpé, A. T. (2016, September). Analyzing potential demand for local rice in West Africa. In 2016 AAAE Fifth International Conference, September 23-26, 2016, Addis Ababa, Ethiopia (No. 249281). African Association of Agricultural Economists (AAAE).

Fofana, I., Goundan, A., \& Domgho, L. V. M. (2014). Impact simulation of ECOWAS rice selfsufficiency policy, IFPRI Discussion Paper 1405. Washington, DC: International Food Policy Research Institute, http://ebrary.ifpri.org/cdm/ref/collection/p15738coll2/id/128894.

Gyimah-Brempong, K., \& Kuku, O. (2016). Evolution of consumption and demand patterns. The Nigerian Rice Economy: Policy Options for Transforming Production, Marketing and Trade, 21-50.

Gustavsen, G.W. (2015). Consumer Cohorts and Demand Elasticities. European Review of Agricultural Economics. 42: 217-37.

INSAE (2018). Evolution hebdomadaire de prix des produits de grande consommation au Benin 
RGPH (2013). Principaux indicateurs socio-démographiques et économiques. Accessible at http://benin.opendataforafrica.org

Laroche Dupaze, C. and Postelle, A. (2013). Food sovereignty and agricultural trade policy commitments: how much leeway do West African nations have. Food policy, 38, 115-125.

Leather, H. D., \& Foster, P. (2004). The World Food Problems towards Ending Undernutrition in the Third Word.

Lusk, J. L. \& Tonsor G. T. (2016). How Meat Demand Elasticities Vary with Price, Income, and Product Category. Applied Economic Perspectives and Policy (2016) volume 38, number 4, pp. 673-711.

McFadden, D., \& Train, K. (2000). Mixed MNL models for discrete response. Journal of applied Econometrics, 15(5), 447-470.

Mhlanga, S. (2010). Economic analysis of consumer based attributes for rice in Benin (Master's Thesis, McGill University).

Naseem, A., Mhlanga, S., Diagne, A., Adegbola, P. Y., \& Midingoyi, G. S. K. (2013). Economic analysis of consumer choices based on rice attributes in the food markets of West Africa- the case of Benin. Food security, 5(4), 575-589.

World Food Program, WFP (2014). Analyse Global de la Vulnérabilité et de la Sécurité Alimentaire (AGVSA, 2013). Service de l'Analyse de la Sécurité Alimentaire (VAM), 142p.

World Food Program, WFP (2017). Analyse Global de la Vulnérabilité et de la Sécurité Alimentaire (AGVSA, 2017). Service de l'Analyse de la Sécurité Alimentaire (VAM), 173p.

Piggott, N. E., and T. L. Marsh (2004). Does Food Safety Information Impact US Meat Demand? American Journal of Agricultural Economics 86: 154-74.

Pinstrup-Andersen, P., \& Caicedo, E. (1978). The potential impact of changes in income distribution on food demand and human nutrition. American Journal of Agricultural Economics, 60(3), 402-415.

Reardon, T. (1993). Cereals demand in the Sahel and potential impacts of regional cereals protection. World Development 21, 17-35.

Rutsaert, P., Demont, M., \& Verbeke, W. (2013). Consumer Preferences for Rice in Africa. In Realizing Africa's rice promise (pp. 294-302). CABI.

Seale Jr., J., Regmi, A., and Berstein, J. (2003). International Evidence on Food Consumption Patterns. United States Department of Agriculture, Economic Research Service. Technical Bulletin Number 1904

Seck, P. A., Touré, A. A., Coulibaly, J. Y., Diagne, A., \& Wopereis, M. C. (2013). Africa's rice economy before and after the 2008 rice crisis. Realizing Africa's rice promise, 24-34. 
Tonsor, G. T., Mintert J., and Schroeder T. C. (2010). U.S. Meat Demand: Household Dynamics and Media Information Impacts. Journal of Agricultural and Resource Economics 35: 1-17.

Train, K. E. (2009). Discrete choice methods with simulation. Cambridge university press.

Unnevehr, L., Eales, J., Jensen, H., Lusk, J., McCluskey, J., \& Kinsey, J. (2010). Food and consumer economics. American Journal of Agricultural Economics, 92(2), 506-521.

USDA (United State Department of Agriculture). 2005 International Food Consumption Patterns estimation. 


\section{APPENDIX}

Table 1: Covariance of Alternative Specific Constants for Random Parameters models by income group and location

\begin{tabular}{|c|c|c|c|c|c|c|}
\hline & \multirow[b]{2}{*}{ Pooled } & \multicolumn{3}{|c|}{ Income Groups } & \multicolumn{2}{|c|}{ Locations } \\
\hline & & $\begin{array}{c}\text { Low } \\
\text { Income }\end{array}$ & $\begin{array}{l}\text { Middle } \\
\text { Income }\end{array}$ & $\begin{array}{c}\text { High } \\
\text { Income }\end{array}$ & $\begin{array}{c}\text { Rural } \\
\text { Area }\end{array}$ & $\begin{array}{c}\text { Urban } \\
\text { area }\end{array}$ \\
\hline HQI, HQD & $\begin{array}{c}0.097 \\
(0.345)\end{array}$ & $\begin{array}{l}1.537 * \\
(0.694)\end{array}$ & $\begin{array}{c}0.311 \\
(0.631)\end{array}$ & $\begin{array}{c}3.298 \\
(1.735)\end{array}$ & $\begin{array}{c}0.22 \\
(0.48)\end{array}$ & $\begin{array}{l}1.92 * \\
(0.84)\end{array}$ \\
\hline HQI, LQD & $\begin{array}{c}0.01 \\
(0.357)\end{array}$ & $\begin{array}{l}0.464 \\
(0.7)\end{array}$ & $\begin{array}{c}0.806 \\
(0.751)\end{array}$ & $\begin{array}{l}3.318 \\
(1.73)\end{array}$ & $\begin{array}{c}0.05 \\
(0.46)\end{array}$ & $\begin{array}{l}1.37 * \\
(0.65)\end{array}$ \\
\hline HQI, Yam & $\begin{array}{l}1.59^{* * * *} \\
(0.369)\end{array}$ & $\begin{array}{c}0.278 \\
(0.616)\end{array}$ & $\begin{array}{c}0.793 \\
(0.735)\end{array}$ & $\begin{array}{c}1.751 \\
(1.676)\end{array}$ & $\begin{array}{c}2.27 * * * \\
(0.54)\end{array}$ & $\begin{array}{c}2.76 * * * \\
(0.64)\end{array}$ \\
\hline HQI, CAS & $\begin{array}{c}0.825 \\
(0.448)\end{array}$ & $\begin{array}{c}0.218 \\
(0.626)\end{array}$ & $\begin{array}{c}0.265 \\
(0.801)\end{array}$ & $\begin{array}{c}2.04 \\
(1.814)\end{array}$ & $\begin{array}{l}1.03^{*} \\
(0.47)\end{array}$ & $\begin{array}{c}1.91 * * \\
(0.65)\end{array}$ \\
\hline HQI, Corn & $\begin{array}{c}0.463 \\
(0.411)\end{array}$ & $\begin{array}{c}0.313 \\
(0.627)\end{array}$ & $\begin{array}{c}0.815 \\
(0.757)\end{array}$ & $\begin{array}{c}2.188 \\
(1.665)\end{array}$ & $\begin{array}{c}1.44 * * \\
(0.55)\end{array}$ & $\begin{array}{c}1.62 * * \\
(0.62)\end{array}$ \\
\hline HQD, LQD & $\begin{array}{c}2.205 * * * \\
(0.377)\end{array}$ & $\begin{array}{c}1.386 \\
(0.872)\end{array}$ & $\begin{array}{c}0.902 \\
(0.636)\end{array}$ & $\begin{array}{c}1.883^{* *} \\
(0.717)\end{array}$ & $\begin{array}{c}0.4 \\
(0.52)\end{array}$ & $\begin{array}{c}4.4 * * * \\
(1.1)\end{array}$ \\
\hline HQD, Yam & $\begin{array}{c}1.844 * * * \\
(0.367)\end{array}$ & $\begin{array}{c}0.648 \\
(0.939)\end{array}$ & $\begin{array}{l}0.568 \\
(0.49)\end{array}$ & $\begin{array}{l}1.993 * * \\
*(0.564)\end{array}$ & $\begin{array}{ll}0 & (0.53)\end{array}$ & $\begin{array}{c}4.06 * * * \\
(1.09)\end{array}$ \\
\hline HQD, CAS & $\begin{array}{l}1.283^{* *} \\
(0.414)\end{array}$ & $\begin{array}{c}0.109 \\
(0.853)\end{array}$ & $\begin{array}{c}0.402 \\
(0.596)\end{array}$ & $\begin{array}{c}3.715^{* *} \\
(1.192)\end{array}$ & $\begin{array}{l}1.1 \\
(0.57)\end{array}$ & $\begin{array}{c}3.35 * * \\
(1.08)\end{array}$ \\
\hline HQD, & $\begin{array}{c}2.849 * * * \\
(0.399)\end{array}$ & $\begin{array}{c}1.004 \\
(0.883)\end{array}$ & $\begin{array}{c}2.018 \\
* * * \\
(0.593)\end{array}$ & $\begin{array}{c}0.433 \\
(0.592)\end{array}$ & $\begin{array}{l}1.14 * \\
(0.56)\end{array}$ & $\begin{array}{c}5.14 * * * \\
(1.11)\end{array}$ \\
\hline LQD, Yam & $\begin{array}{c}2.125^{* * * *} \\
(0.224)\end{array}$ & $\begin{array}{c}1.618 * * * \\
(0.37)\end{array}$ & $\begin{array}{c}2.392 \\
* * * \\
(0.366)\end{array}$ & $\begin{array}{c}0.608 \\
(0.501)\end{array}$ & $\begin{array}{c}1.66 * * * \\
(0.42)\end{array}$ & $\begin{array}{c}2.53 * * * \\
(0.49)\end{array}$ \\
\hline LQD, CAS & $\begin{array}{c}2.106 * * * \\
(0.257)\end{array}$ & $\begin{array}{c}1.682 * * *( \\
0.37)\end{array}$ & $\begin{array}{c}2.355 \\
* * * \\
(0.455)\end{array}$ & $\begin{array}{c}1.222 . \\
(0.727)\end{array}$ & $\begin{array}{c}0.29 \\
(0.51)\end{array}$ & $\begin{array}{c}2.62 * * * \\
(0.41)\end{array}$ \\
\hline LQD, & $\begin{array}{l}1.67 * * * \\
(0.187)\end{array}$ & $\begin{array}{l}1.074 * * \\
(0.361)\end{array}$ & $\begin{array}{c}2.78 \\
* * * \\
(0.333)\end{array}$ & $\begin{array}{c}0.788 \\
(0.507)\end{array}$ & $\begin{array}{c}1.76 * * * \\
(0.38)\end{array}$ & $\begin{array}{c}1.86 * * * \\
(0.38)\end{array}$ \\
\hline Yam, CAS & $\begin{array}{c}0.473 \text {. } \\
(0.261)\end{array}$ & $\begin{array}{l}0.695^{*} \\
(0.321)\end{array}$ & $\begin{array}{c}0.564 \\
(0.367)\end{array}$ & $\begin{array}{l}1.776^{*} \\
(0.761)\end{array}$ & $\begin{array}{l}0.97 * \\
(0.47)\end{array}$ & $\begin{array}{c}0.86 \text { *** } \\
(0.25)\end{array}$ \\
\hline Yam, Corm & $\begin{array}{c}1.854 * * * \\
(0.173)\end{array}$ & $\begin{array}{c}2.015 * * *( \\
0.249)\end{array}$ & $\begin{array}{c}1.674 \\
* * * \\
(0.327)\end{array}$ & $\begin{array}{c}1.159 * * \\
(0.356)\end{array}$ & $\begin{array}{c}1.19 * * \\
(0.38)\end{array}$ & $\begin{array}{c}1.79 * * * \\
(0.19)\end{array}$ \\
\hline CAS, Corn & $\begin{array}{c}0.168 \\
(0.207)\end{array}$ & $\begin{array}{c}0.311 \\
(0.229) \\
\end{array}$ & $\begin{array}{c}0.469 . \\
(0.28)\end{array}$ & $\begin{array}{c}0.3 \\
(0.409) \\
\end{array}$ & $\begin{array}{c}1.04 * * * \\
(0.25) \\
\end{array}$ & $\begin{array}{c}0.14 \\
(0.17) \\
\end{array}$ \\
\hline
\end{tabular}

Standard errors in parenthesis; '***', '**', '*', significance at 1,5 , and $10 \%$.

HQIR: High quality imported rice; HQDR: High quality domestic rice; SQDR: Standard quality domestic rice; CAS: Cassava. 
Table 2: Correlation Matrices for Random Parameters Implied by the Variance-Covariance Matrix

\begin{tabular}{|c|c|c|c|c|c|c|}
\hline Pooled & HQI & HQD & LQD & Yam & CAS & Corn \\
\hline HQI & 1 & 0.0047 & 0.0004 & 0.052 & 0.0347 & 0.0144 \\
\hline HQD & 0.0047 & 1 & 0.294 & 0.2004 & 0.1794 & 0.2937 \\
\hline LQD & 0.0004 & 0.294 & 1 & 0.1925 & 0.2455 & 0.1435 \\
\hline Yam & 0.052 & 0.2004 & 0.1925 & 1 & 0.0449 & 0.1298 \\
\hline CAS & 0.0347 & 0.1794 & 0.2455 & 0.0449 & 1 & 0.0151 \\
\hline Corn & 0.0144 & 0.2937 & 0.1435 & 0.1298 & 0.0151 & 1 \\
\hline \multicolumn{7}{|c|}{ Low income } \\
\hline HQI & 1 & 0.0559 & 0.015 & 0.0067 & 0.0081 & -0.0084 \\
\hline HQD & 0.0559 & 1 & -0.3459 & -0.1203 & 0.0313 & -0.2067 \\
\hline LQD & 0.015 & -0.3459 & 1 & 0.2678 & 0.4312 & 0.1971 \\
\hline Yam & 0.0067 & -0.1203 & 0.2678 & 1 & 0.1325 & 0.2751 \\
\hline CAS & 0.0081 & 0.0313 & 0.4312 & 0.1325 & 1 & 0.0658 \\
\hline Corn & -0.0084 & -0.2067 & 0.1971 & 0.2751 & 0.0658 & 1 \\
\hline \multicolumn{7}{|c|}{ Middle income } \\
\hline HQI & 1 & 0.0247 & 0.0516 & -0.0527 & -0.0212 & 0.0405 \\
\hline HQD & 0.0247 & 1 & 0.1135 & 0.0741 & -0.0633 & 0.1969 \\
\hline LQD & 0.0516 & 0.1135 & 1 & 0.2514 & 0.2988 & 0.2186 \\
\hline Yam & -0.0527 & 0.0741 & 0.2514 & 1 & 0.0742 & 0.1511 \\
\hline CAS & -0.0212 & -0.0633 & 0.2988 & 0.0742 & 1 & -0.0461 \\
\hline Corn & 0.0405 & 0.1969 & 0.2186 & 0.1511 & -0.0461 & 1 \\
\hline \multicolumn{7}{|c|}{ High income } \\
\hline HQI & 1 & 0.1713 & 0.1503 & 0.1063 & 0.0741 & 0.1428 \\
\hline HQD & 0.1713 & 1 & 0.148 & 0.21 & 0.2344 & 0.0491 \\
\hline LQD & 0.1503 & 0.148 & 1 & 0.0558 & -0.0672 & -0.0778 \\
\hline Yam & 0.1063 & 0.21 & 0.0558 & 1 & -0.1309 & 0.1535 \\
\hline CAS & 0.0741 & 0.2344 & -0.0672 & -0.1309 & 1 & 0.0238 \\
\hline Corn & 0.1428 & 0.0491 & -0.0778 & 0.1535 & 0.0238 & 1 \\
\hline \multicolumn{7}{|c|}{ Rural area } \\
\hline HQI & 1 & 0.0149 & -0.005 & 0.1199 & 0.0707 & 0.0715 \\
\hline HQD & 0.0149 & 1 & 0.1226 & 0 & 0.2325 & -0.1741 \\
\hline LQD & -0.005 & 0.1226 & 1 & 0.3965 & 0.0901 & 0.3951 \\
\hline Yam & 0.1199 & 0 & 0.3965 & 1 & -0.1598 & 0.1416 \\
\hline CAS & 0.0707 & 0.2325 & 0.0901 & -0.1598 & 1 & -0.161 \\
\hline Corn & 0.0715 & -0.1741 & 0.3951 & 0.1416 & -0.161 & 1 \\
\hline \multicolumn{7}{|c|}{ Urban area } \\
\hline HQI & 1 & 0.0415 & 0.0267 & 0.0465 & 0.039 & 0.0266 \\
\hline HQD & 0.0415 & 1 & 0.1915 & 0.1531 & 0.1531 & 0.1886 \\
\hline LQD & 0.0267 & 0.1915 & 1 & 0.0859 & 0.1079 & 0.0615 \\
\hline Yam & 0.0465 & 0.1531 & 0.0859 & 1 & 0.0307 & 0.0513 \\
\hline
\end{tabular}


Table 2. (Continued).

\begin{tabular}{lllllll}
\hline Urban area & HQI & HQD & LQD & Yam & CAS & Corn \\
\hline CAS & 0.039 & 0.1531 & 0.1079 & 0.0307 & 1 & 0.0049 \\
Corn & 0.0266 & 0.1886 & 0.0615 & 0.0513 & 0.0049 & 1 \\
\hline
\end{tabular}

HQIR: High quality imported rice; HQDR: High quality domestic rice; SQDR: Standard quality domestic rice; CAS: Cassava.

Table 3: Main Effects Orthogonal Design Used in the Choice Experiment Survey (FCFA/kg)

\begin{tabular}{|c|c|c|c|c|c|c|c|}
\hline Question & HQIR & HQDR & SQDR & Yam & Cassava & Corn & Block \\
\hline 1 & 900 & 300 & 150 & 100 & 75 & 50 & 1 \\
\hline 2 & 900 & 500 & 350 & 500 & 75 & 200 & 1 \\
\hline 3 & 900 & 700 & 550 & 300 & 75 & 400 & 1 \\
\hline 4 & 1300 & 700 & 350 & 100 & 250 & 50 & 1 \\
\hline 5 & 1300 & 300 & 550 & 500 & 250 & 200 & 1 \\
\hline 6 & 1300 & 500 & 150 & 300 & 250 & 400 & 1 \\
\hline 7 & 1100 & 500 & 550 & 100 & 450 & 50 & 1 \\
\hline 8 & 1100 & 700 & 150 & 500 & 450 & 200 & 1 \\
\hline 9 & 1100 & 300 & 350 & 300 & 450 & 400 & 1 \\
\hline 10 & 1300 & 500 & 550 & 500 & 75 & 50 & 2 \\
\hline 11 & 1300 & 700 & 150 & 300 & 75 & 200 & 2 \\
\hline 12 & 1300 & 300 & 350 & 100 & 75 & 400 & 2 \\
\hline 13 & 1100 & 300 & 150 & 500 & 250 & 50 & 2 \\
\hline 14 & 1100 & 500 & 350 & 300 & 250 & 200 & 2 \\
\hline 15 & 1100 & 700 & 550 & 100 & 250 & 400 & 2 \\
\hline 16 & 900 & 700 & 350 & 500 & 450 & 50 & 2 \\
\hline 17 & 900 & 300 & 550 & 300 & 450 & 200 & 2 \\
\hline 18 & 900 & 500 & 150 & 100 & 450 & 400 & 2 \\
\hline 19 & 1100 & 700 & 350 & 300 & 75 & 50 & 3 \\
\hline 20 & 1100 & 300 & 550 & 100 & 75 & 200 & 3 \\
\hline 21 & 1100 & 500 & 150 & 500 & 75 & 400 & 3 \\
\hline 22 & 900 & 500 & 550 & 300 & 250 & 50 & 3 \\
\hline 23 & 900 & 700 & 150 & 100 & 250 & 200 & 3 \\
\hline 24 & 900 & 300 & 350 & 500 & 250 & 400 & 3 \\
\hline 25 & 1300 & 300 & 150 & 300 & 450 & 50 & 3 \\
\hline 26 & 1300 & 500 & 350 & 100 & 450 & 200 & 3 \\
\hline 27 & 1300 & 700 & 550 & 500 & 450 & 400 & 3 \\
\hline
\end{tabular}

HQIR: High quality imported rice; HQDR: High quality domestic rice; SQDR: Standard quality domestic rice 